response on Earth occurs in this region, because the huge Eurasian landmass is very sensitive to seasonal changes in precession forcing.

A comparison $(b$ and $d$ ) of modelled low-latitude and high-latitude responses over the last glacial cycle indicates a great deal of similarity. The precipitation curve is phase-shifted with respect to temperature, because the effect of ice sheets has been included in the former ${ }^{2}$ but not the latter. Even though the simulated temperature curve is for a largely ice-free region $^{8}$, timing of temperature variations could also be shifted somewhat in this area as a result of downwind influence from ice sheets.

It therefore seems that northern wetlands could also be the source of changes in methane during the ice age. It may not be possible to use climate models to discriminate between low- and highlatitude methane sources, but methane isotope studies may in future shed light on the problem, as low- and highlatitude wetland methane sources differ

\title{
Bird community structure
}

SIR - A recent paper from our research group $^{1}$ pointed out that the correlation between abundance and body size among species within tribes of British birds is frequently positive, particularly when a tribe has no close phylogenetic relatives in Britain. Our investigations of a similar pattern occurring in local, single-habitat communities suggest that the date at which a tribe radiated, rather than the

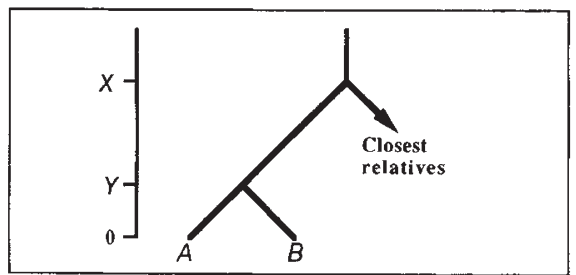

A tribe of birds consisting of two extant species ( $A$ and $B$ ) shared their most recent common ancestor with each other $Y$ time units ago and their most recent common ancestor with other birds $X$ time units ago. The measure $Y$ is a better predictor than is $X$ of the correlation between population density and body size within tribes.

date at which it originated, is a better predictor of the correlation between abundance and body size. In other words, the date $X$ in the figure may have been a surrogate for date $Y$ (or some measure closely correlated with $Y$ ). Any explanation of the original result will need to take account of this finding.

We have examined data from 90 bird communities sampled from small areas (10-100 ha) of defined habitat throughout the world ${ }^{2}$. Nee et al. used a measure of the time at which members of a tribe last shared a common ancestor with in their carbon-isotope signatures by about 12 parts per thousand (for example, ref. 9).

\section{Applied Research Corporation}

\section{Arguello Drive,}

College Station, Texas 77840, USA

1. Chappellaz, J., Barnola, J. M., Raynaud, D., Korotke vich. Y. S. \& Lorius, C. Nature 345, 127-131 (1990) Prell, W. L. \& Kutzbach, J. E. J. geophys. Res. 92 $8411-8425$ (1987)

3. Imbrie, J. et al. in Milankovitch and Climate (eds Berger, A. L., Imbrie, J., Hays, J., Kukla, G. \& Saltzman, B.) 269-305 (Reidel, Dordrecht, 1984).

4. Berger, A. L. \& Pestiaux, P. in Milankovitch and Climate (eds Berger, A. L., Imbrie, J., Hays, J., Kukla, G. \& Saltzman, B.) 83-111 (Reidel, Dordrecht, 1984). Woillard, G. M. Quat. Res. 9, 1-21 (1978).

5. Woillard, G. M. Quat. Res. 9, 1-21 (1978).

6. Molfino, B., Heusser, L. H. \& Woillard, G. M. in Hays, J., Kukla, G. \& Saltzman, B.) 391-404 (Reidel, Dordrecht, 1984)

7. Matthews, E. \& Fung, I. Global Biogeochem. Cycles 1 , 61-86 (1987).

8. Short, D. A., Mengel, J. G., Crowley, T. J., Hyde, W. T. \& North, G. R. Quat. Res. 35, 157-173 (1991).

9. Quay, P. D., King, S. L., Lansdown, J. M. \& Wilbur, D. O. Global Biogeochem. Cycles 2, 385-397 (1988)

10. Guiot, J., Pons, A., de Beaulieu, J. L. \& Reille, M Nature 338, 309-313 (1989).

11. Crowley, T. J., Short, D. A., Mengel, J. G. \& North, G. R. Science 231, 579-584 (1986)

12. Hyde, W. T., Crowley, T. J., Kim, K.-Y. \& North, G. R. J. Clim. 2, 864-887 (1989) Milankovitch and Climate (eds Berger, A. L., Imbrie, J.

ecological guild structure. Whether the date of radiation might be interpreted in like manner remains a subject for investigation. We shall describe elsewhere how body-size abundance patterns differ when we compare (1) a tribe's relatedness to the other tribes in its community rather than to other tribes in the world; and (2) single-habitat communities with geopolitical regions, such as Britain or Sweden.

Peter Cotgreave

PAUL H. HARVEY

AFRC Unit of Ecology and Behaviour,

Department of Zoology,

University of Oxford,

Oxford OX1 3PS, UK

\section{Iron still comes from above}

SIR - Sunda et al. ${ }^{1}$ report that open ocean phytoplankton require very little iron indeed; less than $10 \%$ of the minimum amounts thought necessary to meet the metabolic needs of plant cells for growth based on iron enzymatic requirements for photosynthesis, respiration and $\mathrm{NO}_{3}$ reduction ${ }^{2}$. They suggest that we should reassess our conclusion that amounts of dissolved iron in open ocean upwelling water are too low, and that this essential element must be supplied from atmospheric deposition.

We recently measured ${ }^{3}$ dissolved iron in the equatorial Pacific $\left(0^{\circ} ; 140^{\circ} \mathrm{W}\right)$, and we were unable to detect $(<0.02$ nmol kg ${ }^{-1}$ ) this essential element at 60 $\mathrm{m}$, the depth of maximum upwelling ${ }^{4}$. Assuming that the iron concentration is

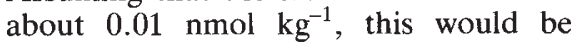
enough to permit the phytoplankton to produce only $5 \mu \mathrm{mol}$ carbon based on the very high $500,000 \mathrm{C} / 1 \mathrm{Fe}$ ratio reported by Sunda et al. ${ }^{1}$. On the other hand, the $\mathrm{NO}_{3}$ at $60 \mathrm{~m}, 8.1 \mu \mathrm{mol} \mathrm{kg}{ }^{-1}$, would support the production of 20 times more carbon based on the redfieldian ratio of $6.6 \mathrm{C} / 1 \mathrm{~N}$. The situation is worse south of the Equator $\left(3^{\circ} \mathrm{S}\right.$; $\left.140^{\circ} \mathrm{W}\right)$. Here, dissolved Fe concentrations do not begin to increase systematically beyond $0.04 \mathrm{nmol} \mathrm{kg}{ }^{-1}$ until a depth of $150 \mathrm{~m}$ is exceeded. I still believe that open ocean 'diatomic' iron comes from above, not from below. In areas like the equatorial Pacific, where little or none comes from above, a deficiency of this element limits phytoplankton growth.

JOHN H. MARTIN

1. Nee, S., Read, A. F., Greenwood, J. J. D. \& Harvey, P. H. Nature 351, 312-313 (1991)

2. Nee, S., Harvey P. H. \& Cotgreave P. in Genetic Conservation and Sustainable Development (eds Hindar, K., Sandlund, O. T. \& Brown, A. H. D.) (Nonwegian University Press (Universitetsforlaget) with Oxford University Press, in the press).

3. Fisher, R. A. \& Yates, F. Statistical Tables for Biological Agricuitural and Medical Research.6th edn (Longman, London, 1975)

4. Sibley, C. G. \& Ahlquist, J. E. Phylogeny and Classification of Birds. A Study in Molecular Evolution (Yale, New Haven, 1990)
Moss Landing Marine Laboratories, Moss Landing, California 95039, USA

1. Sunda, W. G., Swift, D. G. \& Huntsman, S. A. Nature 351, 55-57 (1991).

2. Raven, J. A. New Phytol. 20, 279-287 (1988).

3. Martin, J. H. in Primary productivity and biogeochemical Cycles in the Sea (ed. Falkowski, P.) Brookhaven Symposium, Upton, New York, (in the press).

4. Barber, R. T. \& Chavez, F. P. in ASLO Symp. Lake San Marcos, California (eds Chisholm, S. W. \& Morel, F. M. M.) (in the press). 